\title{
About a Will to Power: Post-cold War Conflicts and the Politics of Knowledge Production
}

\section{Zubairu Wai}

University of Toronto Scarborough (Toronto, Canada)

What is needed is a new kind of imperialism, one compatible with human rights and cosmopolitan values: an imperialism which aims to bring order and organisation, but which today rests on the voluntary principle.

Robert Cooper

Why We Still Need Empires

This paper proposes a critical interrogation of the dominant interpretations of the post-cold war conflicts in order to demonstrate their political nature and how they internalised the causes of conflicts. By internalisation, I refer to the move to locate the causes of conflicts in internal sources. It argues that the region of emergence of the dominant interpretations of conflicts-the so-called new wars - and the internalisation of their causes is the attempt by the West to ideologically suppress or discredit third world anticolonial solidarity and worldmaking. To make this argument, the paper pays specific attention to the broader historical contexts and structural conditions within which internalisation emerged, which it argues are significant for understanding not only the political nature of the dominant interpretations of conflicts, but also the material forces and social processes that informed their production and circulation. In other words, that the framing of the post-cold war conflicts and the internalisation of their causes were never innocent or impartial acts of knowledge production, but political, ideological, and temporal acts linked to power, interests, and specific agenda.

Keywords: New Wars, Third Worldism, contemporary conflicts, knowledge production. 
mensely powerful statement about the political nature of the knowledge regimes that came to define the dominant understandings of contemporary conflicts. Policy-relevant research, they tell us, often gets started when a "convergence of political factors, academic interests, and policy concerns", lead to the establishment of research agendas. "Political factors" is in fact a euphemism for the role that power or vested political interests of especially hegemonic actors played in setting the research agendas for investigating and interpreting these conflicts. What is revealing about Malone and Sherman's celebration of this coming afoot of "policy relevant research" is not so much that certain types of research inform policy, but that power informs such research agendas and makes them possible (Mudimbe, 1988; Wai, 2012).

With specific reference to the post-cold war conflicts - the so-called new wars (Kaldor, 2001; Münkler, 2004) — and how they came to be apprehended for policy, it was the interests of Northern governments that would ultimately set the agendas for the dominant interpretations of conflicts and what they meant for policy (Wai, 2012; Cooper, 2005; Richards, 2005; Cramer, 2002). While the word "convergence" gives the impression that this was an organic or naturally emergent process characterised by independent (and unrelated) developments (in policy and academic speech) that naturally moved toward a singular point of congealment, the narrative that Malone and Sherman emplot is not convincing that this was the case. What it indicates is different: a political move to redefine conflicts from a perspective that was not only amenable to policy, but also capable of supporting the ethico-political rearming of the West and its attempts to impose a liberal peace on the world. And this occurred on a much larger political, ideological, institutional, and intellectual terrains that cannot simply be reduced to the meaning that the word "convergence" connotes.

In this paper, I propose a critical interrogation of the dominant interpretations of the post-cold war conflicts in order to show the political nature of these interpretations and how they internalised the causes of these conflicts. By internalisation, I refer to the move to locate the causes of conflicts in internal sources. Put differently, it is the assumption that the causes of conflicts are endogenously located in local conditions bound to what is seen as the internal dysfunctions of these societies. My focus is not on explaining the conflicts themselves but on the politics of their interpretation. The argument pursued here is that the region of emergence of the dominant interpretations of the postcold war conflicts, and the internalisation of their causes, is the move by the West to ideologically suppress or discredit Third World anticolonial solidarity and worldmaking (Getachew 2020). Put differently, that the attempt to discredit Third Worldism is the condition of possibility of the dominant interpretations of conflicts and the internalisation of their causes.

As every discourse is emergent within broader sets of material, social, and power relations, so was the attempt to internalise the causes of conflicts steeped in real historical contestations and material processes. As such, both the broader structural and historical conditions of the interpretations of conflicts and the immediate institutional contexts of their framings are significant for understanding not only the political nature of the discourses they produce, but 
also the material forces and social processes that informed their production and circulation. In other words, the framing of the post-cold war conflicts and the internalisation of their causes were never innocent or impartial acts of knowledge production, but political, ideological, and temporal acts linked to power, interests, and specific agendas (Mudimbe, 1988; Wai, 2012).

In what follows, I examine the context within which the dominant explanations that came to define the post-cold war conflicts emerged, and then link it to the broader context and longer history of Western anxieties about Southern societies in two registers. First is the immediate context of the anxiety that the conflicts created about southern societies as a cesspool of disorder, violence, and conflicts that if not contained will spill over and infect the North. Second is the deeper historical anxiety that Southern self-determination and attempts at constructing an alternative architecture of global power, wealth, and ethics caused for Western power. Both anxieties are in fact related. While the post-cold war conflicts can in part be traced to these historical attempts to suppress or gain control over Southern self-determination and delegitimate the politics that drove them, the conflicts themselves provided an opportunity for the realisation of these historical quests of their ideological suppression.

\section{PICK YOUR POISON: CULTURE, IDENTITY, OR ECONOMICS}

Perhaps a good place to start is the unreflective triumphalism in the West at the end of the so-called cold war about the promise of liberalism and unfounded optimism that it would steer the world to an era of peace and prosperity. Completely ignoring how the liberal West foments political violence around the world, the liberal political establishment had come to believe that the demise of the Soviet Union would finally allow the world, under American leadership, to function beyond Soviet and Third World obstructionism and ideological rancour, to establish a liberal world order based on consensus building. In line with this political will of liberal triumphalism, President George Bush had, in the immediate aftermath of the first Gulf War (1990/1991) declared a New World Order in which, under American leadership, the world would experience an era of peace and neoliberal economic prosperity. As a part of that new world order, the United States would, in August 1992, lead a UN peacekeeping mission code-named Operation Restore Hope to Somalia to "pacify" its warring factions, and bring the peace dividend of the American-led new world order. About this same time, UN Secretary-General, Boutros Boutros-Ghali, released his Agenda for Peace (1992) as a blueprint for dealing with post-cold war conflicts and political violence around the world.

This optimism was, however, short-lived. By 1994, Operation Restore Hope had run aground, and United States had been forced to withdraw from Somalia in humiliation. Between April and July of that same year, the Rwandan genocide took place, followed, a year later, by the Srebrenica massacre in Bosnia. Various other conflicts were raging - Liberia, Sierra Leone, Djibouti, Algeria, Georgia, Afghanistan, Tajikistani, Burundi, Congo, Chechnya, Nagorno-Karabakh, and so 
forth. The optimism that had accompanied the end of the cold war had now collapsed and first, turned into despair, then anxiety about a world in disarray and beyond the control of a political will seeking to establish its rule or impose order on it.

As questions about what these conflicts meant, and what to do about them occupied academics and policy makers, American journalist, Robert Kaplan, published his sensational "The Coming Anarchy" (1994) in The Atlantic, tapping into anxieties about Southern conflicts, and defining them, more significantly, in terms that were both intelligible and compelling for Northern policymakers. In a now controverted mishmash of ideas, Kaplan claimed that the conflicts were the manifestations of a new barbarism emergent from the opportunity that the end of the cold war had created for the catalytic exertions of long suppressed ethno-identitarian hatred into violent and intractable conflicts. These reversions to primitive barbarism were being fanned by resurgent tribalisms (ethnic hatred) and Malthusian pressures: demographic stress amidst resource scarcity, environmental degradation, runaway disease and crime, and fierce competition over scarce resources. The resulting conflicts represented nihilistic violence in which "loose molecules" battle each other to establish tribal fiefdoms, as the nation-state withered, and international borders got eroded and became meaningless. This was a reality that had already taken hold in the former Yugoslavia and especially West Africa and portended the frightening apocalyptic future that awaited most of the rest of the world. And since these conflicts were cultural and identitarian, they would be difficult, if not impossible, to resolve.

By investing a political objective onto the framing of these conflicts, Kaplan had made them intelligible to Northern policy makers by tapping into anxieties about the Global South as a cesspool of primitive violence, political disorder, and intractable conflicts that had dire implications for world order and Northern security. Because they were emanating from the "uncivilized" South, Kaplan seemed to be suggesting, these conflicts represented an existential threat to the North. And this framing made it safe to disengage these conflicts from larger structural and historical processes and think about them as endogenously produced and locally bound to the internal dysfunction in Southern states and societies in which they occurred.

While these ideas would initially come to inform Western, especially US policy toward conflicts in Africa and Eastern Europe after the Somali debacle -Bill Clinton reportedly credited his decision not to intervene in Bosnia to Kaplan's thesis - concerns about their implications for policy, specifically, how to respond to the strategic dangers they purportedly represented for Northern security, forced a number of Northern institutions and academics to begin searching for alternative explanations beyond Kaplan's coming anarchy, which appeared to have been confirmed in the minds of many Northern policy makers by the humiliating withdrawal of US forces from Somalia, and the Rwandan and Bosnian genocides. But Rwanda and Bosnia had another ring to them: they also made urgent, at least for the liberal left, the question of what to do about conflicts that threatened the logic of a liberal world order. Many, especially on the liberal left, who might have agreed, in principle, with the picture Kaplan 
painted of a world in distress and out of control, "tended to recoil in righteous horror" from its implications (Cramer, 2002), seeing it as a disabling ideological posture of the political right that was incapable of providing ethical answers for the question the conflicts raised. British political scientist, David Keen, for example, put it rather bluntly:

This kind of analysis can easily feed into rightist political agendas, notably the idea that "we in the West" need somehow to steel ourselves against the coming anarchy, whether through isolationism, or a strong military, or both (Keen, 2000: 141).

This however is a misreading, or at least a partial reading: Kaplan's thesis needs not lead to isolationism - and except for a brief moment after the US withdrawal from Somalia, and the policy inertia that failed to prevent the Rwandan and Bosnian genocides, it did not- for it could be, and was in fact, eventually read as an invitation for the West to protect itself by taking up "the white man's burden" and intervene to impose order on the world since not doing so would have implications for their own security. Robert Cooper, adviser to former British Prime Minister Tony Blair, for example, justified his calls for "a new imperialism" (2002) on this ground. As well, the attempt by the United States to impose an American "peace" upon the world through routinised militarised interventions and banalisation of war post-9/11 was partially informed by this logic. The argument went like this: since wars and conflicts "create zones of lawlessness open to exploitation by criminals and terrorists" (DFID 2004: 3), and the violence and disorder these conflicts engender cannot be contained by frontiers, for they tend "to spread, whether in the form of refugee flows, terrorism, or illicit trafficking in drugs, weapons, and even human beings" (Annan, 2004), intervening to stem them and tackle the conditions that give rise to them is a self-interested "political imperative-central to our long-term national security and peace" as former British Prime Minister Gordon Brown once stated (quoted in Duffield, 2007: 2). Liberal peace and its interventionist strategies stem precisely from this logic.

The point I am making is that ultimately Kaplan won; for in the end, it was his framing of these conflicts as existential threat and security challenge for Northern policy makers that, for better or for worse, set the terms of the debates that followed and the condition for policy action. Even when cast in purely altruistic terms, that is, in terms of responding to humanitarian disasters and complex emergencies, it was the security and ideological concerns of the North that ultimately justified intervention. However, an enabling discourse that the liberal left was comfortable with in formulating an interventionist strategy needed to be found to reconcile the objectives of intervention with their justification, and this would be found in economistic explanations of conflict, which became an "analytical godsend to those made viscerally anxious by the 'senseless anarchy' story" (Cramer, 2002: 1848), since it made the actions of "even vicious warlords" comprehendible within the limits of economic rationality, which in turn gestured toward the possibility of using various types of incentives "to change the opportunity costs of conflicts" (Cooper, 2005: 465). 
It was in the aftermath of the Rwandan and Bosnian genocides that policy began to seriously look for a credible discourse amenable to its objectives of interventions. At the same time, several Western scholars -Keen (1998); see also Berdal and Keen (1997), Duffield (2001), Reno (1998, 2000), Collier (2000), Collier and Hoeffler (1998, 1999, 2000, 2001), among others- began focusing more explicitly on the economic agendas that they claimed were the primary drivers of conflicts. This was no mere coincidence. Taking their cue from the policy interests of Western governments, especially Canada and the UK after Tony Blair's New Labour which came to power in 1997, and global governance institutions such as the UN, World Bank and IMF which actively encouraged and supported them, these commentators began to focus on what they called the political economy of conflicts and proposed various economistic explanations that would eventually consolidate around the "greed and grievance" thesis, after a 1999 conference in London, organised by the International Peace Academy (IPA) and funded by the Canadian and British governments, brought together many of the scholars who have come to be associated with this perspective.

The story of the conference, as told by Malone and Sherman (2005) in terms of the power and the interests that drove its agenda, the way the issues were framed, how a set of given criteria and parameters were fixed, adopted, and imposed on how to view and talk about conflicts, what to look for and what not to look for, the set of foundational assumptions immanent in the frames and parameters, is telling of the complicitous relationship between power and knowledge. In bringing together some of the most powerful institutions and voices working on conflicts in the West, the conference helped to not only frame what these conflicts were about but gave its stamp of approval to the notoriously simplistic and reductive "greed and grievance" thesis (Wai, 2012).

Emphasising the centrality of economic agendas, and especially, the rational calculations of actors, these analysts argued that what appeared new about these conflicts was "the degree to which the resources themselves had emerged not as a means to an end but as the very object of struggle" (Arnson, 2005: 3). Understood as part of what Mary Kaldor (2001) designates as "new wars", that is, a new kind of intrastate/regionalised violence characterized by the increasing overlap between economic and political motives, terrorism and crime, ethnicity and religion, localised and globalised forms of violence and so forth, which "can be contrasted with earlier wars in terms of their goals, the methods of warfare and how they are financed" (Kaldor, 2001: 6; see also Münkler, 2004; Duffield, 2001, and Newman, 2004), these conflicts, they tell us, are less about ideology and politics, and more about economics. Driven by natural resource predation, which not only finances high levels of violence, but also blurs the lines between war and crime, these conflicts collapse the local and the global through parallel transnational networks of actors who engage in profitable crime under the cover of war.

The resulting war economies, constituted at the intersection of violent conflicts, state failure, organised crime, and illegal transborder activities money laundering, gun running, illicit trade in conflict diamonds, illegal drug trade and so forth - become alternative means of pursuing power and wealth through the manipulation of violence and disorder (Duffield, 2001; Keen, 1998; 
Berdal and Keen, 1997; Berdal and Malone, 2000; Reno, 1998). Thus, far from being irrational, we are told, the violence perpetrated in these conflicts is a well orchestrated rational economic calculation by elites who benefit from violence and disorder. War then constitutes "the continuation of economics by other means" as Keen (1998: 11) famously put it.

Much of the early literature advancing this economistic perspective emerged from the British academy - for instance, some of the earliest reflections appeared in the Adelphi Papers, a series of policy-oriented occasional papers published by the International Institute for Strategic Studies (IISS) in London. However, the most influential of these economistic explanations came from Paul Collier (himself a British economist), then Director of the World Bank Development Research Group, and his main collaborator Anke Hoeffler, an economist at the Centre for the Study of African Economies (CSAE) at Oxford University. Unlike the others - Berdal, Duffield, Keen, Reno, and so forth - who posited neoliberal political economy arguments to explain the economic agendas that they claimed were driving conflicts, Collier and Hoeffler imported econometric models to give quantitative dimensions to an already growing economistic interpretations of conflicts.

If the political economists were at least willing to consider politics, albeit as a function of economic rationality, the neoclassical economists completely jettisoned it, arguing that conflicts occur not because of political disaffection ("grievance"), inequality, or ethnic polarisation (tribalism), but mainly because of "greed" - those causal factors broadly consistent with economic motivation of actors. Claiming a greater predictive power for greed or "loot motivation", than for grievance or "justice motivation", they fixed the parameters of conflicts as resolutely economic, not in a Marxian sense which would have required them to take seriously the structural and systemic conditions of capitalist exploitation and inequality, but in a neoliberal economic sense that reduce social relations to market mechanisms and limits economic rationality to atomised market relations (Collier and Hoeffler, 1998, 1999, 2000).

As such, two versions of the same perspective ultimately emerged: a neoliberal political economy approach that uses qualitative methods and, at least, considers politics, a politics that is still the function of economic rationality, and neoclassical econometric approach that uses quantitative methods, rejects politics as a causal explanation, and accounts for conflicts in "loot motivation" and primary commodity predation (Collier and Hoeffler 1998). However, both are ultimately economistic explanations, informed by methodological individualism and the theoretical assumptions of rational choice. They both stress the economic motives and agendas of actors, and reduce conflictual processes to atomistic relations and rational economistic calculations. Fixated on causation, that is, looking for causes, identifying the motives of actors, and typologizing them according to forms (Duffield 2001), they see conflicts as temporalized and spatialised phenomena detached from broader contexts, and locally bound to the internal dysfunction of the states and societies within which they occur. This penchant for internalisation, thus, functions as a mechanism of concealing Western complicity in the politics that animate conflicts. 
Apart from the obvious pathologization of the groups and the societies in which these conflicts occur, the stress on local factors, and the nature of violence, even when interpreted as 'rational' responses to economic stimuli, and the moralistic language that is used to describe the violence, also helps in both evicting the agents from the human, and discrediting, or delegitimating the political projects that they proclaim, while conversely legitimating external intervention as an antidote to the madness that they represent. Obsessed with the instrumental value of their interpretations, these perspectives construct mechanistic conceptions that reduce conflictual processes to atomistic relationships and/or statistical formulas. Through this, they evacuate history, sack the social, write over politics, and obscure the complex social processes that animate conflicts (Cramer 2002; Wai 2012). However, having the imprimatur of the World Bank, the United Nations, and major Northern governments gave these economistic perspectives a credibility and influence far beyond its analytical value and insight.

\section{THE REGION OF EMERGENCE OF INTERNALISATION}

An extensive critique of these perspectives and the explanations they foreground has been presented elsewhere (Wai, 2012), as such; it is not my intention to rehearse them here. What I want to do instead, is attend to the broader structural and historical conditions that necessitated and thus explains the internalisation of the causes of conflicts in the South. I focus specifically on the anti-colonial period, and the historical contestations between the North and South, and the move by the former to ideologically suppress Third World anticolonial solidarity and worldmaking. This, I argue, is key to understanding both the post-cold war conflicts, as well as how they came to be interpreted and accounted for.

In this regard, I want to take the 1950s as my vantage point. The anti-colonial movement is in full swing: India had gained independence in 1947 and was using its position in the United Nations to support Third World demands for decolonisation. The communist revolution had succeeded in China in 1949 causing anxieties for a West reeling from World War II and stumbling onto the Cold War. Everywhere in the South, colonised peoples were rising to demand self-rule. However, most colonial powers were reluctant to relinquish empire. The French, for example, held on to their colonial vision and became even more repressive. In 1954, they suffered a major defeat at Den Bien Phu at the hands of Ho Chi Minh's Viet Minh forces. That same year, the Algerian revolution began with FLN attacks on French positions in Algiers and elsewhere in the country. Meanwhile, between 1955 and 1966, four major conferences took place -two Afro-Asian solidarity meetings in Bandung (1955) and Cairo (1961); the inaugural meeting of the Non-Aligned Movement in Belgrade (1961), and the TriContinental meeting in Havana (1966) — at which a radical vision was mapped out for anti-colonial liberation and solidarity, as well as a new global architecture of anti-imperialist worldmaking (Prashad, 2008; Getachew, 2020).

From the vantage point of the imperial centres of London, Paris, Washington, and elsewhere in the colonial capitalist metropoles, however, 
these developments, especially in the context of an intensifying cold war, were frightening and anxiety inducing. The colonised were speaking in the language of radical transformation that is not afraid to use violence as specified by Frantz Fanon, the foremost theorist of anti-colonial revolution in The Wretched of the Earth. Decolonisation, Fanon would write, was not just about replacing one species of beings with another, but about the bringing afoot of a new human through violence. And as events in Vietnam, Algeria, Cuba, and elsewhere in the world were demonstrating, violence was indeed a medium of anticolonial liberation and revolutionary praxis. What this meant, in other words, was that the coloniality of Western power and privilege was being challenged, not only by Soviet communism, but also anticolonial revolution and solidary. Even more frightening was the seeming ideological overlap between third worldist positions and those of the Soviet-led Eastern bloc, even though the former espoused nonalignment and anti-colonial solidarity as the basis of its politics.

In the context of the cold war, however, any attempt at questioning the coloniality of the prevailing global system, espousing independent sovereign perspective in global affairs, and experimenting with alternative state making and economic development strategies was seen as siding with the Soviet Union. Thus, as Southern societies were attaining independence, so did efforts to gain control over those newly decolonised states intensify. The genocidal violence against communists in Indonesia and the subsequent overthrow of Sukarno, one of the major architects of Bandung and Third Worldism, the murder of Lumumba months after Congolese independence, the CIA instigated coup against Kwame Nkrumah, as well as American involvement in the Mozambican and Angolan civil wars, and in Indochina, first through bankrolling the French military and eventually through the murderous aggression that was the Vietnam war, the blockade of Cuba, the CIA sponsored coups against Salvador Allende in Chile, and Maurice Bishop in Grenada, American proxy war on Guatemala, and support for the apartheid regime in South Africa, and so forth, were all attempts at not only destabilising Southern states that espoused self-determination and alternative path to economic development, but seeking to recolonise these states through attempts at imposing regimes amenable to American interests. The resulting violence, instability, and displacements, in the form of conflicts, refugee flows, poverty, and underdevelopment, and so forth, as exemplified by the root causes debate in the United Nations in the 1980s (Duffield, 2001) were explained, not as a result of these neo-colonial and imperialist assaults on these states, but as endogenously produced conditions.

Ideological and political differences between Western and third worldist positions were also mirrored by analytical schemas that stressed different causal factors in explaining global realities, especially around poverty and economic development. Mainly through Marxist inspired theories - dependency and world systems theories - that insisted on the co-production of Western affluence and wealth and third world misery and poverty, the third world position was that inequality in the global system and the way in which Western wealth was created was directly responsible for poverty, underdevelopment, and sociopolitical problems in the south, and as such, demanded a fair and equitable 
"redistribution of the world's resources, a more dignified rate of return for the resources and labour power of their people, a shared acknowledgement of the heritage of science, technology and culture" (Prashad, 2007: 17). In contrast was the orthodox Western position that through evolutionist preconceptions and ideologies of modernisation regarded third world poverty and underdevelopment as endogenous conditions derived primarily from the backwardness of their economies, societies, and cultural institutions, conditions that could only be overcome through the infusion of Western capital, investment, technology, and knowledge systems. In other words, poverty and underdevelopment in the South owed not to histories of colonialism and Western imperial exploitation, but to the fact that Third World societies were "traditional" societies that had not yet fully modernised and made the full transition to capitalism.

The clashes between these positions at the United Nations as attested to by both the NIEO (New International Economic Order) debates in the 1970s, and the 'root causes' debates in the 1980s, were often heated and polarised. Mark Duffield (2001) regards them as important moments for the internalisation of the causes of conflicts in the 1990s. And though crucial to the defeat of Third Worldism and the advancement of the West's preferred ideological positions on Southern crises, Duffield does not take their political implications seriously for the 'moral rearming of the West', rejecting claims that liberal power and the system it legislates is imperialistic - he has since abandoned this position (see Duffield 2007). It is precise the politicality of this moment, which Duffield downplays, that is significant, for it both demonstrates the political nature of how the West's preferred interpretations became hegemonic and how third worldist positions were ideologically suppressed and discredited. My contention therefore is that it was political move to suppress and discredit Third Worldism that explains the condition of possibility of the dominant interpretations of conflicts and the internalisation of their causes.

Designating a number of proposals for the transformation of the structural makeup of global economy, the NIEO was a third wordlist strategy for redressing the structural imbalances of the global economy. It sought to strengthen the position of the third world in areas such as trade, industrialization, investment, finance, agriculture, economic sovereignty, marketing and pricing, and so forth, through global income redistribution and the involuntary transfer of wealth and technology from the Western industrialised capitalist core to the poorer nations of the Global South. Proposed at the Non-Alignment Movement conference in Algiers in September 1973, it was tabled and adopted at a Special Session of the UN General Assembly in May 1974. However, its adoption by the UN General Assembly met with stiff opposition from the Western imperialist powers led by the United States, Britain, and France, who saw it as an attack on Western power, privilege and wealth, and did everything to not only defeat it, but also discredit the ideas that made it possible.

Space will not allow me to explore, in detail, how this process of defeating the NIEO and third worldist solidarity politics that produced it took place. What is important however is that the neoliberal ascendancy through which the NIEO was defeated was both a mechanism for crisis displacement as well as an assault 
on third worldist solidarity politics that made the politics of the NIEO possible. It was, as Peter Gowan (1999) shows, the United States' gamble of a triple strategy of high oil pricing, the removal of capital controls, and high interest rates in the 1970s that put in place a new international financial and monetary arrangement that recentred the United States as the dominant player, giving it far greater "influence over the international monetary and financial relations of the world than it had enjoyed under the Bretton Woods rules" (24). This system, however, operated on the logic of crisis as it systematically generated balance of payments, debt, and financial crises in the South, while presaging neoliberal measures as a solution. Through these internationally provoked crises, the International Monetary Fund (IMF) and the World Bank acquired new roles as major players. From then on, a powerful US Treasury with unparalleled powers over the World Bank and IMF forced poorer states of the south into compliance with Washington's preferred economic policies through credit manipulation, debt management practices and austerity measures.

Through structural adjustments policies (SAP) marketed and enforced as the panacea to economic crises and development problem, the IMF and World Bank opened Southern economies to neoliberal mechanisms that enforced, among other things, privatisation, trade liberalisation, deregulation of capital, and the erosion of the public sector and national control over policies and so forth. The weight of structural adjustment conditionalities and a crippling debt burden would in turn force these states to not only abandon domestic commitment to certain statist redistributive programmes - rolling back of spending in such vital areas as healthcare, food, education, transport, and infrastructure and the elimination of subsidies on key sectors such as agriculture- but also the pursuit of collective international economic and political agendas as the growing pressures and demand of debt repayment, which made focus on domestic economic and socio-political issues a priority, forced them to divert attention from the collectivist project that had been spearheaded by the third world movement.

Conflicts in places such as Africa emerged precisely in these political and economic contexts, which also explains and accounts for them in an essential way. In this climate, ideas that sourced Southern poverty and underdevelopment in colonial capitalist modernity and imperialist exploitation would come to be discredited, and the South would be made to accept responsibility for past and ongoing crises and failures - even the ultimate failure of the SAPs would be blamed on the internal dynamics of these hapless states - as the West's preferred explanations for crises eclipsed other competing explanations and become hegemonic. In turn, Third Worldism lost its relevance as a coherent political movement and ideological expression of significance (Duffield, 2001: 29-30; Prashad, 2008; Westlake, 1991).

Like the polarised contestations over NIEO, the 'root cause debate' on refugee flows in the UN General Assembly in the 1980s was the other moment that significantly impacted the way conflicts in the 1990s came to be interpreted (Duffield 2001). The debate was initiated in the General Assembly's Special Political Committee in response to increasing population displacements, mass forced migration and refugee outflows in the Global South. Beginning especially 
with the events surrounding the birth of Bangladesh in March 1971, through the rising tides of displacements and refugee flows from Ethiopia, Angola, Mozambique and Southern Africa as a result of the anti-colonial and liberation struggles in the mid to late 1970s, there was from the 1970s onwards a steady stream and increase in world refugee populations, which the UN Commission for Human Rights saw as a human rights issue. Mirroring the NIEO debates, the West stressed factors bound to local conditions while Third World and socialist opinion stressed external factors bound to the historical and structural conditions of global political economy: legacies of colonialism, global inequality, growing balance of payments problems and deteriorating terms of trade and so forth.

Though two separate UN reports were produced from the debate - the first by Sadruddin Aga Khan in 1981, and the second in 1985 when the neoliberal ascendancy was already underway-, it was the 1981 report that proved significant for a number of reasons. First, it was one of the very first influential policy studies to clearly conceptualise problems of population displacement and mass exodus in terms of "root causes". Second, it largely emphasised internal factors like repressive regimes, human rights violations, poverty, and underdevelopment, and so forth, factors that would become significant in accounting for "root causes" of conflicts in the 1990s. Third, it framed the refugee problem in terms of human rights, providing the first clear statement that linked refugee flows with human right violations (Duffield, 2001: 26-27). These three elements of the report - discussing the refugee problem in terms of root causes, locating those causes in internal factors, conceptualising them as a human rights issue and linking them with development malaise- would become the major characteristics of approaches to conflicts in the 1990s. And this move to internalise and relativise the causes of conflicts and political instability within the south would subsequently be amplified and cemented in Western academic and policy speech as the shift to neoliberalism disciplined alternative Southern explanations and came to eventually shape the conventional understandings of conflicts and political violence in the 1990s and beyond.

It is important that the fact that the West's preferred explanations for crises in the South became hegemonic owes not to analytical soundness or intellectual superiority, but power. Western governments "used their power over research funding, over publications, and especially over credit to propel their interpretation of the facts to a dominant position. In a volatile, highly politicised world where those who had power over credit effectively had power over life and death this was not so difficult" (Bienefeld, 1988: 70). In Africa for example, neopatrimonialism as a tell-all conceptual approach to the continent's political and economic problems emerged and became dominant during this period.

\section{CODA}

Every discourse, Mudimbe (1988) reminds us, has a region of emergence and conditions of possibility, that is, the sociohistorical region of its emergence and the frames that make its production possible. It is usually these frames that 
make particular types of knowledge possible, and also accounts for them in an essential way. And it is in diagnosing this region of emergence and its condition of possibility that we realise that the framing or interpretation of phenomena, especially, highly politicised phenomena such as conflicts, are never innocent or impartial acts of knowledge production, but political, ideological, and temporal acts linked to specific interests and political and ideological agendas. What I have tried to do in this paper is highlight the political nature of the knowledge regimes about contemporary conflicts, by specifying their regions of emergence and the politics that make them possible. I have suggested that the dominant perspectives on contemporary conflicts and the discourses and interpretations they fashion are not disinterested and impartial acts of knowledge production, but political processes tied to larger ideological and political agendas.

As every system of domination requires a legitimating frame to validate its logic, and a politics to define its authority (Mudimbe, 2013), so did the post-cold war liberal will to power require a discourse to assure the credibility of its politics and justify the necessity of its intervention. In this sense, the dominant framings of conflicts were not mere scholarly exercise, but political interventions linked to power, the imprimatur of which made their analysis possible and to which they submitted the conflicts. Through this, I have attempted to make a broader claim about the complicity of Western intellectual production in the political and ideological interests of the west and the way such productions function as instruments of power (Spivak, 1988). The idea that there is a complicitous relationship between knowledge and power, and more importantly, that there is an inseparability of Western will to truth and will to power is not today a controversial claim. Knowledge, we know, does not exist in a vacuum. Produced for a specific audience and specific purpose, it speaks to its condition of production and the power that makes it possible. Put differently, the way Southern realities are apprehended, especially in relation to conflicts, political violence, and so-called state failure, have not been neutral acts of knowledge production, scholarly reflection, social inquiry, or academic exercise, but part of the political processes of knowing and mapping these societies for a system to conquer and impose its will on them.

As knowledge is always for someone or some purpose, they have been targeted at a specific audience, creating certain possibilities for the enactment of certain types of power relations, which invariably are reflected in the articulation of certain types of policies and political interventions. Specifically, they have been very instrumental in the formulation and universalisation of the liberal peace agenda, a political project and neo-imperialist posture, authored by the North as the panacea for Southern problems.

Zubairu Wai (zuba.wai@utoronto.ca) is Associate Professor of Political Science and Global Development Studies at the
University of Toronto, Canada. He is the author of Epistemologies of African Conflicts: Violence, Evolutionism, and the War in Sierra 
Leone (2012), which won the ATWS Toyin Falola Africa Book Award for 2013, and coeditor (with Marta Iñiguez de Heredia) of Recentering Africa in International Relations: Beyond Lack, Peripherality, and Failure (2018). His research takes up epistemological questions regarding the nature and conditions of disciplinary knowledge in
International Relations, Development Studies, Conflict and Security Studies, and African Studies. Specifically, he focuses on how the intersections of power and coloniality frame the discourses and political economy of knowledge, violence, conflict, development, and state formation in Africa, and the Global South more broadly.

\section{References}

Annan, Kofi (2004). "In Haiti for the Long Haul”. Wall Street Journal (16 March).

Arnson, Cynthia J. (2005). "The Political Economy of War: Situating the Debate". In: Arnson, Cynthia and Zartman, I. William (eds.). Rethinking the Economics of War: The Intersection of Need, Creed and Greed. Washington, DC, and Baltimore: Woodrow Wilson Centre Press \& The John Hopkins University Press, pp. 1-22.

Ballentine, Karen (2004). "Final Report: Program on Economic Agendas in Civil Wars: Principal Research Findings and Policy Recommendations". New York: International Peace Academy.

Berdal, Mats and Keen, David (1997). "Violence and Economic Agendas in Civil Wars: Some Policy Implications". Millennium: Journal of International Studies, 26(3), pp. 795-818.

Berdal, Mats and Malone, David M. (ed.) (2000). Greed and Grievance: Economic Agendas in Civil Wars. Boulder, CO: Lynne Rienner.

Bienefeld, Manfred (1988). "Dependency Theory and the Political Economy of Africa's Crises". Review of African Political Economy, 15(43), pp. 68-87.

Collier, Paul (2000). "Doing Well Out of War". In: Berdal, Mats and Malone, David M. (eds.). Greed and Grievance: Economic Agendas in Civil Wars. Boulder, CO: Lynne Rienner, pp. 91-111.
Collier, Paul and Hoeffler, Anke (1998). "On Economic Causes of Civil War". Oxford Economic Papers, 50(4), pp. 563-573.

-. (1999). "Justice- Seeking and LootSeeking in Civil War". Mimeo. Washington, DC: World Bank.

-. (2000). "Greed and Grievance in Civil War". Policy Research Working Paper, 2355. Washington, DC: The World Bank.

-. (2001). "Greed and Grievance in Civil War". Mimeo. Washington, DC: World Bank.

Cooper, Robert (2000). "Why We Still Need Empires". The Observer, (Sunday 7 April 2002). Retrieved at <https://www.theguardian.com/ observer/worldview/story/0,11581,680117, 00.html>

Cramer, Christopher (2002). "Homo Economicus Goes to War: Methodological Individualism, Rational Choice and the Political Economy of War". World Development, 30(2), pp. 1845-1864.

Cooper, Neil (2005). "Picking the Pieces of the Liberal Peaces: Representations of Conflict Economies and the Implication for Policy". Security and Dialogue, 36(4), pp. 463-478.

DFID (2004). The Africa Conflict Prevention Pool: An Information Document. London: Department for International Development.

Duffield, Mark (2001). Global Governance and New Wars: The Merging of Development and Security. London: Zed Books. 
-. (2007). Development, Security and Unending War: Governing the World of Peoples. Cambridge: Polity.

Fanon, Frantz (1963). The Wretched of the Earth. New York: Grove.

Getachew, Adom (2020). Worldmaking after Empire: The Rise and Fall of Self-Determination. Princeton, NJ: Princeton University Press.

Gowan, Peter (1999). The Global Gamble: Washington's Faustian Bid for World Domination. London: Verso.

Harris, Nigel (1987). The End of the Third World: Newly Industrialising Countries and the Decline of an Ideology. New York: Meredith Press.

Kaldor, Mary (2001). New and Old Wars: Organized Violence in a Global Era. Stanford, CA: Stanford University Press.

Kaplan, Robert (1994). "The Coming Anarchy: How Scarcity, Crime, Overpopulation, and Disease are Rapidly Destroying the Social Fabric of Our Planet". The Atlanti, (February), pp. 44-76.

Keen, David (1998). "The Economic Functions of Violence in Civil War". Adelphi Paper, 320. London: International Institute for Strategic Studies.

-. (2000). "Organised Chaos: Not the New World Order We Ordered". In: O'Meara, Patrick; Mehlinger, Howard D., and Krain, Mathew (eds.). Globalisation and the Challenge of a New Century: A Reader. Bloomington: Indiana University Press, pp. 140-148.

Malone, David M. and Sherman, Jake (2005). "Economic Factors in Civil Wars: Policy Considerations". In: Arnson, Cynthia and Zartman, I. William (eds.). Rethinking the Economics of War: The Intersection of Need, Creed and Greed. John Hopkins University Press, pp. 234-255.

Mudimbe, Valentin-Yves (1988). The Invention of Africa: Gnosis, Philosophy and the Or- der of Knowledge. Bloomington and Indianapolis: Indiana University Press.

-. (2013). On African Fault Lines: Meditations on Alterity Politics. Pietermaritzburg.

Münkler, Herfried (2004). The New Wars. Cambridge: Polity.

Newman, Edward (2004). "The 'New Wars' Debate: A Historical Perspective Is Needed". Security Dialogue, 35(2), pp. 173-189.

Prashad, Vijay (2008). The Darker Nations: A People's History of the Third World. New York: The New Press.

Reno, William (1998). Warlord Politics and African States. Boulder, CO: Lynne Rienner.

-. (2000). "Shadow States and the Political Economy of Civil Wars". In: Berdal, Mats and Malone, David M. (eds.). Greed and Grievance: Economic Agendas in Civil Wars, Boulder, CO: Lynne Rienner, pp. 43-68.

Richards, Paul (1996). Fighting for the Rain Forest: War, Youth and Resource in Sierra Leone. London and Oxford: The International African Institute and James Currey.

-. (2005). "New War: An Ethnographic Approach". In: Richards, Paul (ed.). No War, No Peace: An Anthropology of Contemporary Armed Conflicts. Athens, $\mathrm{OH}$ and Oxford: Ohio University Press and James Currey, pp. 1-22.

Spivak, Gayatri Chakravorty (1988)."Can the Subaltern Speak?". In: Nelson, Cary., and Grossberg, Lawrence (eds.). Marxism and the Interpretation of Culture. London: Macmillan Education, pp. 271-313.

Wai, Zubairu (2012). Epistemologies of African Conflicts: Violence, Evolutionism, and the War in Sierra Leone. New York: Palgrave Macmillan.

Westlake, Melvyn (1991). "The Third World (1950-1990) RIP". Marxism Today, (August), pp. 14-16. 